\title{
Meta-analyzing ownership concentration and firm performance in Asia: Towards a more fine-grained understanding
}

\author{
Pursey P. M. A. R. Heugens • Marc van Essen • \\ J. (Hans) van Oosterhout
}

Published online: 25 September 2008

(C) The Author(s) 2008. This article is published with open access at Springerlink.com

\begin{abstract}
We present a meta-analysis of the relationship between concentrated ownership and firm financial performance in Asia. At the cross-national level of analysis, we find a small but significant positive association between both variables. This finding suggests that in regions with less than perfect legal protection of minority shareholders, ownership concentration is an efficient corporate governance strategy. Yet, a focus on this aggregate effect alone conceals the existence of true heterogeneity in the effect size distribution. We purposefully model this heterogeneity by exploring moderating effects at the levels of owner identity and national institutions. Regarding owner identity, we find that our focal relationship is stronger for foreign than for domestic owners, and that pure "market" investors outperform "stable" or "inside" owners whom are multiply tied to the firm. Regarding institutions, we find that a certain threshold level of institutional development is necessary to make concentrated ownership an effective corporate governance strategy. Yet we also find that strong legal protection of shareholders makes ownership concentration inconsequential and therefore redundant. Finally, in jurisdictions where owners can easily extract private benefits from the corporations they control, the focal relationship becomes weaker, presumably due to minority shareholder expropriation.
\end{abstract}

Authors are listed alphabetically. A shorter version of this paper is included in the 2008 Academy of Management Best Paper Proceedings. We are indebted to APJM guest editors Eric Gedajlovic and Mick Carney for their editorial guidance, and to two anonymous reviewers for their insightful feedback. A special word of thanks goes out to Tammo Bijmolt and David Wilson, who graciously supplied us with methodological advice. We are nevertheless responsible for any remaining errors.

P. P. M. A. R. Heugens $(\bowtie) \cdot$ M. van Essen · J. (Hans) van Oosterhout RSM Erasmus University, P.O. Box 1738, 3000 DR Rotterdam, The Netherlands e-mail: pheugens@rsm.nl

M. van Essen

e-mail: messen@rsm.nl

J. (Hans) van Oosterhout

e-mail: joosterhout@rsm.nl 
Keywords Meta-analysis · Meta-analytic regression analysis . Ownership concentration · Firm performance - Owner identity .

Private benefits of control

\section{Introduction}

According to one influential definition, the field of corporate governance "deals with the ways in which suppliers of finance to corporations assure themselves of getting a return on their investment" (Shleifer \& Vishny, 1997: 737). Correspondingly, to secure their investments and enforce their claims to residual earnings, investors have the choice between two broad governance strategies. The first is for them to rely on the disciplinary force of external governance systems, like capital markets and the legal system, to offer some form of protection against managerial opportunism or expropriation by controlling shareholders (Gillan, 2006; Walsh \& Seward, 1990). The second is to concentrate their ownership, such that they can exert direct influence on top managers to run the firm in their interest (Bolton \& von Thadden, 1998; Coffee, 1991; Maug, 1998; Shleifer \& Vishny, 1986). In the present paper we explore corporate governance choices in the Asian context. Characteristic for this region is that investors here have opted massively for the governance strategy of concentrated ownership (Carney \& Gedajlovic, 2002; Claessens, Djankov, \& Lang, 2000; La Porta, López-de-Silanes, \& Shleifer, 1999).

It is commonly held that concentrated ownership offers the best protection to shareholders when legal protection is relatively weak, as is the case in most Asian jurisdictions (Denis \& McConnell, 2003). In this view, acquiring greater control over corporations serves to fill the "institutional void" (Khanna \& Palepu, 2000) left by weak or ineffective legal and financial institutions. Yet this explanation seems overly crude, as it cannot account for the fact that although concentrated ownership is an endemic feature of practically all Asian economies, the levels of protection offered to shareholders differ greatly across Asian jurisdictions (Djankov, La Porta, López-de-Silanes, \& Shleifer, 2008). Another recalcitrant finding that necessitates us to qualify the institutional voids explanation is that concentrated ownership has remained remarkably stable over time, in spite of the fact that corporate governance standards and legal institutions catering to shareholders' needs have improved markedly in many Asian jurisdictions over the past two decades (e.g., Douma, George, \& Kabir, 2006; Gedajlovic, Yoshikawa, \& Hashimoto, 2005). This warrants a more fine-grained and contextualized account of the costs and benefits of concentrated ownership in Asia; one that takes into account the subtly different institutional and corporate governance configurations that can be found within the Asian context. The present paper aims to provide such an account. It seeks to answer three salient questions about concentrated ownership in Asia in particular.

First, given that ownership concentration is a widely used strategy through which investors aim to ensure some reasonable return on their investment (Shleifer \& Vishny, 1997), we question the effectiveness of this broad corporate governance 
strategy within the Asian context. More particularly we ask: Do firms held by concentrated owners outperform dispersedly owned firms in Asian jurisdictions? Second, we explore the emerging insight in the corporate governance literature that the relationship between ownership concentration and corporate performance is likely to be moderated by the identity of the concentrated owner. Various strategies for distinguishing between different kinds of concentrated owners exist. One is to differentiate "foreign" from "domestic" owners (Douma et al., 2006). Another is to classify owners alternatively as "stable," "market," or "inside" investors (Gedajlovic et al., 2005; Gerlach, 1992). With respect to both of these common classifications, the question we ask is: Does the identity of the concentrated owner matter to the performance of Asian firms? Third, in line with the varieties of capitalism literature (Hall \& Soskice, 2001; Hollingsworth \& Boyer, 1997), and the notion of institutional complementarity more specifically (e.g., Aoki, 2001), we assume that the associational strength of the relationship between ownership concentration and firm performance in Asia will differ from jurisdiction to jurisdiction, due to subtly different institutional configurations that have resulted from historically differing paths of institutional development (Peng \& Jiang, 2006). Our aim is to uncover the specific institutional contingencies which make ownership concentration a more or less effective corporate governance strategy in each of the Asian nations in our sample. In other words: Is the relationship between ownership concentration and firm performance in Asia moderated by jurisdiction-level institutions?

To address these three research questions, we require a database which is simultaneously broad, deep, and historical (including as many countries, firms, and observation years as possible). We have compiled and analyzed such a database with the help of meta-analytical techniques (Hedges \& Olkin, 1985; Lipsey \& Wilson, 2001). Our final database covers 11 Asian countries and 660,087 firm-year observations, derived from 65 primary studies and expressed in the form of 290 effect sizes. Specifically, we employed two groups of meta-analytical calculations. To address research questions one and two, we used the meta-analytic methods pioneered by Hedges and Olkin (1985). Due to its more precise and parsimonious character (Rosenthal, 1991), this type is preferable to the presently more popular artifact-corrected form of meta-analysis (Hunter \& Schmidt, 2004) when the underlying data involve accurately measured economic variables. To address research question three, we used meta-analytic regression analysis (Lipsey \& Wilson, 2001). The benefit of meta-analytic regression is that it allows us to assess whether jurisdiction-level moderating effects on the associational strength of the focal relationship still hold in the presence of plausible control variables. ${ }^{1}$ Finally, this paper demonstrates that meta-analysis is a very powerful methodological tool to unpack the overall relationship between concentrated ownership and firm performance in Asia, as it is capable of providing a more fine-grained understanding of its

\footnotetext{
${ }^{1}$ In the words of Miller and Cardinal (1994: 1653): "analyzing [moderator] variables simultaneously in a multiple regression format allows proper assessment of the relative explanatory power of each variable because those variables directly compete against one another in the same statistical analyses."
} 
cost and benefits in a part of the world in which it has historically been highly prevalent.

\section{Theory and research on concentrated ownership}

Ownership concentration and firm performance in Asia

The empirical corporate governance literature offers no unequivocal answer to the costs and benefits of concentrated ownership. Some scholars have found a positive association with corporate performance (La Porta, López-de-Silanes, Shleifer, \& Vishny, 2000a), others a negative association (Loderer \& Martin, 1997), and still others a curvilinear relationship (Morck, Shleifer, \& Vishny, 1988). Theoretically compelling arguments can be furnished in favor of each finding.

Positive effects of concentrated ownership In a select number of jurisdictions around the world, dispersed ownership is the norm. This is especially the case in Anglo-Saxon jurisdictions such as the US and the UK (La Porta et al., 1999). An important weakness of dispersed ownership, however, is that dispersed owners lack both the means and the motive to address managerial agency problems. In the presence of information asymmetry and interest misalignment between the owner/ principal and the manager/agent, problems associated with managerial opportunism - such as lack of effort, on-the-job consumption, and empire building-loom large (Fama \& Jensen, 1983; Jensen \& Meckling, 1976). In jurisdictions with dispersed ownership, in which principals are typically both unwilling and unable to act as effective monitors of publicly listed firms, the markets for corporate control, equity capital, and executive talent are therefore the primary disciplinary forces that keep managers in check (Gillan, 2006; Walsh \& Seward, 1990). Yet in settings where such markets are underdeveloped, as is often the case in Asia, investors have no choice but to accept their role as firm monitors, which they can only exercise effectively by concentrating their equity holdings. Concentrated ownership gives them both more powerful incentives to become involved in governance, as well as a means to influence managers by means of direct access strategies and the threat of using their concentrated voting rights (David, Hitt, \& Liang, 2007). Concentrated shareholders can thus stimulate or even coerce the corporate leadership to work in their interest. Additionally, in less antagonistic settings concentrated shareholders can also use their vast resources and prior knowledge to enhance managerial and organizational capabilities (Carney \& Gedajlovic, 2001; Weidenbaum \& Hughes, 1996). Having a wealthy, concentrated owner can also help firms in times of crisis, as such owners sometimes choose to transfer private resources into an ailing firm. This phenomenon, also known as "propping," can help firms survive a temporary slump in performance, when owners choose "to invest private cash today in order to preserve their options to expropriate and to obtain a legitimate share of profits tomorrow" (Friedman, Johnson, \& Mitton, 2003: 734). Hence as a general matter, a positive relationship is to be expected 
between ownership concentration and corporate performance in the Asian context. See Hypothesis 1a:

Hypothesis 1a In Asia, ownership concentration is positively related to corporate performance.

Negative effects of concentrated ownership Although concentrated owners have the power to induce management to run the firm in their interest, these interests need not converge with those of minority shareholders. Corporate governance scholars have traditionally focused on the consequences of interest divergence between managers and shareholders (Fama \& Jensen, 1983; Jensen \& Meckling, 1976), yet a more recent stream of corporate governance research focuses specifically on large shareholders' attempts to expropriate smaller shareholders (Bae, Kang, \& Kim, 2002; Bertrand, Mehta, \& Mullainathan, 2002). This phenomenon is generally known as "tunneling," and is commonly defined as "the transfer of assets and profits out of firms for the benefit of their controlling shareholders" (Johnson, La Porta, López-de-Silanes, \& Shleifer, 2000: 22). Whereas tunneling can occur at all times, it is especially common in times of economic or financial crisis. During crises, corporate wealth is siphoned off by controlling shareholders to escape their own creditors, while better-performing firms are called upon by their underperforming affiliates to "bail them out" (Gedajlovic \& Shapiro, 2002; Granovetter, 2005). In general, tunneling is easier when the dominant shareholder is also a director of the firm. In such cases, the intent to disadvantage minority shareholders goes hand-in-hand with the legal authority to make executive decisions on corporate transactions, thereby creating a vicious conjunction of shareholder-manager and shareholder-shareholder agency problems.

In practice, tunneling can take either one of three forms. First, controlling shareholders can transfer resources from the focal firm to other firms they own through self-dealing or related party transactions (Djankov et al., 2008). Commonly, this happens through the use of artificially deflated transfer prices (Johnson et al., 2000) or by means of acquisitions which hurt the focal firm but benefit affiliated firms (Bae et al., 2002). Second, the controlling shareholder can increase his or her share of the firm without transferring any assets, through minority-disadvantaging transactions such as dilutive share issues or minority freeze-outs (Johnson et al., 2000). Third, controlling shareholders who are also directors of the firms can expropriate minority shareholders by setting their own compensation at above-market levels unjustified by performance or effort (Cheung, Stouraitis, \& Wong, 2005). Regardless of form, therefore, tunneling will have detrimental effects on corporate performance. See Hypothesis $1 \mathrm{~b}$ :

Hypothesis 1b In Asia, ownership concentration is negatively related to corporate performance.

Nonmonotonic effects of concentrated ownership A recent meta-analysis of the influence of concentrated ownership on firm performance found that its two focal variables were not connected by a statistically significant relationship (Dalton, Daily, 
Certo, \& Roengpitya, 2003). These findings therefore indicate that in the aggregate the costs and benefits of concentrated ownership may very well cancel each other out. This does not imply that concentrated ownership is inconsequential in all individual cases. There is some evidence suggesting that that the effects of ownership structure on performance are nonmonotonic (Demsetz \& Villalonga, 2001; Morck et al., 1988; McConnell \& Servaes, 1990), and that they vary with the size of the concentrated owner's stake. When a concentrated owner's stake is relatively low, the owner has insufficient control to successfully engage in tunneling or other minority-disadvantaging strategies. Under these conditions, the concentrated owner's most effective strategy for increasing his or her private wealth is to push the management of the firm for greater performance. Hence relatively low levels of concentrated ownership will have an overall positive influence on corporate performance. At higher levels of ownership, however, a point will be reached where the concentrated owner effectively controls the firm, while there is still a significant fraction of small investors to expropriate. Under these conditions tunneling is both feasible and lucrative, and the effect of concentrated ownership on corporate performance will cease to be positive. Since in many jurisdictions dominant shareholders can have control rights in excess of their ownership rights (La Porta et al., 1999), tunneling often becomes a real possibility even with ownership stakes well below 50\%. However, as the concentrated ownership stake increases further, tunneling becomes a less sensible strategy for increasing private wealth, as there will be fewer minority shareholders to expropriate. Tunneling would then simply result in a direct transfer of private wealth from one venture into another, which is unlikely to benefit the concentrated owner, except perhaps for fiscal reasons. As the best strategy for majority owners to increase their private wealth is to gear the firm for higher performance, very large ownership stakes are again likely to have a positive effect on firm performance. Previous research by Morck et al. (1988) has reported a similarly shaped (positive/neutral/positive) nonmonotonic relationship between the degree of ownership concentration and firm profitability. See Hypothesis 1c:

Hypothesis 1c In Asia, the relationship between ownership concentration and corporate performance will follow a nonmonotonic (positive/neutral/positive) pattern.

\section{The identity of concentrated owners}

Our second research question was: Does the identity of the concentrated owner matter to the performance of Asian firms? This question dovetails with the emerging insight that different categories of concentrated owners may have different preferences and priorities with respect to corporate risk, stability, growth, and performance (Douma et al., 2006; Gedajlovic et al., 2005). These differences are likely to moderate the relationship between ownership concentration and performance. Quite a number of classifications pertaining to the identity of corporate owners have been suggested in the literature, but it is beyond the objectives of this paper to discuss them in great detail. Instead, we will focus on two influential categorizations: (1) foreign versus domestic owners (Douma et al., 2006) and (2) 
stable, versus market, versus inside owners (Gedajlovic et al., 2005; Gerlach, 1992). Specifically, we explore whether these identity-based classifications influence the associational strength of our focal relationship.

Foreign versus domestic owners Corporate governance scholars commonly distinguish between foreign and domestic concentrated owners (e.g., Douma et al., 2006). It is generally argued that foreign owners expect and effectuate higher performance than domestic owners. Foreign owners tend to contribute positively to firm performance for two reasons. First, they often contribute to organizational and managerial capabilities by providing knowledge and organizational resources in addition to the financial capital they provide. Chibber and Majumdar (1999), for example, found that foreign owners tend to commit more resources to knowledge transfer. Similarly, Djankov and Hoekman (2000) found that foreign owners provide companies with generic knowledge like managerial expertise and quality control systems. Second, foreign owners may select for, or contribute to the realization of, good governance practices in the firms they invest in. As foreign owners often own similar firms in different jurisdictions, they tend to have the relevant experience and know-how to set appropriate benchmarks for governance and performance (Douma et al., 2006). Furthermore, experience with corporate governance "best practices" in their home markets often makes it easier for them to select control strategies which align managers' interests with their own. In sum, firms tend to earn positive performance benefits from foreign ownership.

In contrast, domestic ownership in Asia tends to be associated with lower performance. Many domestic owners involve business groups of some sort, that is: "sets of legally separate firms bound together in persistent formal and/or informal ways" (Granovetter, 2005: 429). Although the effect of group ownership on performance differs somewhat across countries (Khanna \& Rivkin, 2001), there are two features of group ownership that tend to have a negative effect on firms' performance in the Asian context. First, many groups have a strong joint identity based on common brands or because they are dominantly owned by a single family (Granovetter, 2005). This instills obligations of inter-firm loyalty in them which make them susceptible to the practice of inefficiently transferring wealth and resources from more profitable firms to other firms in the group that are temporarily or structurally financially constrained (Shin \& Park, 1999). Second, as hinted at before, group structures create opportunities for tunneling, due to the presence of pyramidal control structures and extensive cross-holdings (Bebchuk, Kraakman, \& Trianis, 2000; Bertrand et al., 2002; Johnson et al., 2000). In short, firms owned by domestic parties tend to be outperformed by firms owned by foreign parties. See Hypothesis 2a:

Hypothesis 2a The association between concentrated ownership and firm performance in Asian countries will be more strongly positive when the concentrated owner is foreign, as opposed to domestic.

Stable, market, and inside owners In addition to geographical classifications, controlling parties can also be characterized in terms of the motivations and objectives that pertain to their share ownership (Gedajlovic et al., 2005). An 
influential typology was suggested by Gerlach (1992), who distinguishes between "stable," "inside," and "market" owners. Each of these groups tends to have distinct investment objectives, which we expect to result in differential performance.

Stable investors typically involve parties like affiliated firms, banks, and insurance companies. Characteristic for these investors is that they tend to have multiple ties with the firms in which they own shares. In addition to being shareholders, stable investors are often also creditors, debtors, buyers, suppliers, or alliance partners. Their equity stake primarily serves to cement an often complex set of non-shareholder relationships with the focal firm, and is often reciprocated to create cross-holdings (Roe, 1994). Due to such relational multiplicity, profitability objectives are typically only a secondary consideration for stable investors (Abegglen \& Stalk, 1985; Gedajlovic \& Shapiro, 2002), while also making them highly sensitive to pressures from the focal firm's management (Brickley, Lease, \& Smith, 1988; David, Kochhar, \& Levitas, 1998).

Inside investors are individuals or groups who combine a substantial equity stake with direct managerial control over the firm (Fama \& Jensen, 1983). Although inside owners can be professional managers who have been endowed with a substantial ownership stake in order to align their interests with those of outside owners, in Asia they tend to consist of corporate founders and their immediate families. Although insiders' shareholdings entitle them to a share in the firm's profit stream (Alchian \& Demsetz, 1972), inside owners often do not adopt policies that contribute to the attainment of the highest possible profits for three reasons. First, since inside owners have often locked up a large part of their wealth in the firms they dominantly own, they are suboptimally diversified and hence will be more risk-aversive than more diversified investors (Fama \& Jensen, 1983). Their risk-aversion is likely to put pressure on the firm's profit-generating potential. Second, inside owners often appoint family members rather than external professional managers in key managerial positions (Granovetter, 2005). Insiders make such appointment decisions because they trust relatives more than outsiders or because they simply want to benefit their next of kin (Schulze, Lubatkin, Dino, \& Buchholtz, 2001). Unfortunately, handing over control to individuals lacking managerial experience or even talent usually does not cohere very well with the aim of profit maximization. Third, as explained earlier, the combination of having a group of minority shareholders to exploit and enjoying full-fledged executive powers over the corporation may create opportunities for tunneling that only few inside owners will be able to resist.

Market investors are different from inside and stable investors in that they are typically tied to the firm only with their equity stakes and mostly operate at arm's length from firm management. Market investors thus tend to have maximal equity returns as their primary investment objective (Fukao, 1999). Corporations may be sensitive to the pressures of market investors for two reasons. First, market investors will be less than hesitant to sell their ownership stake when they are dissatisfied with the firm's share performance. This is a powerful disciplining force, since selling-off large blocks of shares is likely to lower the firm's share price and thus increases its cost of equity capital (La Porta, López-de-Silanes, Shleifer, \& Vishny, 2000b). Second, market investors will factor in a risk premium when they fear problems like tunneling or managerial entrenchment - again increasing the firm's cost of equity 
capital. These disciplinary forces make it more likely that the firm's managers will engage in strategies consistent with market investors' investment objectives. In sum, we expect that firms owned by market investors will outperform firms owned by either inside or stable investors. See Hypothesis $2 b$ :

Hypothesis 2b The association between concentrated ownership and firm performance in Asian countries will be more strongly positive when the concentrated owner is a market investor, as opposed to an inside or stable investor.

A common critique of the ownership-performance literature, which potentially undermines the logic behind Hypotheses $2 \mathrm{a}$ and $2 \mathrm{~b}$, is that corporate ownership is an endogenous variable rather than an exogenous influence on firm profitability (Demsetz \& Lehn, 1985). In the words of Demsetz and Villalonga: "the ownership structure of a corporation should be thought of as an endogenous outcome of decisions that reflect the influence of shareholders and of trading on the market for shares" (2001: 210). Most crucial in this respect are the monitoring needs of the firm: when the performance of the firm is more likely to fluctuate due to self-serving managerial behaviors, it is better managed by concentrated owners; when performance is more predictable it is also safe in the hands of dispersed shareholders (Davis, 2005). As an equilibrium outcome, therefore, the effect of ownership on performance is likely to be null (Demsetz \& Villalonga, 2001).

Although the endogeneity critique is elegant and compelling, its validity is critically dependent on the liquidity and informational efficiency of the underlying stock market. Ownership is likely to be endogenous when shareholders have sufficient information about the future (behavioral) performance variability of the companies in which they invest, and when they can costlessly adjust the size of their shareholdings in each accordingly. Very few, if any, stock markets in Asia meet these criteria. Prior research has demonstrated that ownership in Asia is remarkably stable, probably due to the fact that the restructuring of ownership is costly and difficult in illiquid and informationally opaque markets (Douma et al., 2006; Selarka, 2005). In such markets ownership can be treated as an exogenous variable, as investors can neither acquire nor divest controlling blocks without incurring significant costs, and must therefore seek to maximize the performance of corporations given the block of shares they own in them (Stiglitz, 1994). In other words, the Asian context allows us to sidestep the endogeneity critique of the ownership literature.

\section{Country-level moderating effects}

The third research question we raised was: Is the relationship between ownership concentration and firm performance in Asia moderated by jurisdiction-level institutions? The intuition behind this research question rests on the observation that nation-states have very different institutional configurations as a result of historically different development trajectories (Hollingsworth \& Boyer, 1997). Rather than converging into a single "most efficient" capitalist system, these largely idiosyncratic development trajectories have culminated in geo-political "patchworks" in which several "varieties of capitalism" (Hall \& Soskice, 2001) tend to durably coexist (Heugens \& Otten, 2007). Country-level institutions play a large role in 
economic development, as they provide for (social) peace, assure individual freedoms to make investment and purchasing decisions, establish secure and transferable property rights, and enforce contracts through their legal systems (North, 1990). The crucial point, however, is that national systems will provide for these capitalist support functions by means of different institutional configurations. These "social institutions of capitalism" (Heugens, 2007; Heugens, van Oosterhout, \& Vromen, 2003) tend to vary considerably internationally, which makes the relationship between ownership concentration and profitability likely to vary from jurisdiction to jurisdiction (Aguilera \& Jackson, 2003; Hollingsworth \& Boyer, 1997). In the present paper, we will focus on three crucial jurisdiction-level moderating variables: (1) the overall quality of a nation's background institutions; (2) the level of de jure protection a country offers its shareholders against self-dealing by corporate executives (Djankov et al., 2008); and (3) the de facto private benefits a country allows parties to extract from the firms they dominantly own (Dyck \& Zingales, 2004).

Quality of background institutions Although large investors may induce managers to work in their interest by way of the direct, informal access they might enjoy, this influence strategy only works when the relationship between owner and manager is fairly amicable. In most other situations, large shareholders can ultimately govern only by exercising their voting rights. Voting, however, is a relatively inefficient (Easterbrook \& Fishel, 1991) and often ineffective governance mechanism (Bebchuk, 2007). In any case, the effectiveness of voting is critically dependent upon the quality of the legal system and other background institutions (Shleifer \& Vishny, 1997). Majority ownership requires relatively little judicial intervention, as a $51 \%$ ownership stake is both easy to prove and provides a straightforward "unity of command" (David et al., 2007) that clarifies decision making. Things are considerably more complicated for large minority shareholders, however, as they need to make alliances with other investors to exercise control. Because managers can much more easily interfere in these alliances, the need for judicial intervention to enforce shareholder control becomes considerably higher. As a consequence, "large minority share holdings may be effective only in countries with relatively sophisticated legal systems" (Shleifer \& Vishny, 1997: 755). In brief, the quality of a given nation's background institutions (especially but not exclusively its legal system) will influence the associational strength of the relationship between concentrated ownership and performance. See Hypothesis 3a:

Hypothesis 3a The association between concentrated ownership and firm performance is positively moderated by the quality of the background institutions of the firm's home country.

Legal protection against self-dealing In the Asian context, where so many firms have dominant owners (Claessens, Djankov, \& Klapper, 2003; La Porta et al., 1999), minority shareholders have every reason to be more concerned about expropriation by larger shareholders than about the detrimental effects of managerial opportunism. As explained before, they have recourse to two broad governance strategies to remedy such inter-shareholder governance problems: concentrating their ownership in order to become dominant owners themselves or investing only in jurisdictions in 
which a sophisticated legal system offers them sufficient protection against controlling shareholders.

There are two ways in which concentrated ownership and legal protection can relate to each other within a corporate governance regime. First, legal protection and concentrated ownership may be mutually supportive within the configuration of institutional features that constitutes a corporate governance regime. In this view, legal protection and concentrated ownership are complementary institutions (Aoki, 2001: 87ff), and we should expect a positive interaction effect of the joint presence of these two features on corporate performance. But concentrated ownership and legal protection, second, can also be substitutes rather than complements (Shleifer \& Vishny, 1997). Under this scenario, the presence of one of these features in a corporate governance regime is necessary to ensure satisfactory corporate performance, but the addition of the second feature will add little or nothing to that performance. In other words, there will be no positive interaction effect of the two features under conditions of substitution.

The Asian context allows for a concurrent test of these two alternatives. In certain Asian jurisdictions the legal protection against self-dealing transactions is relatively poorly developed. India, Japan, Korea, the Philippines, and Taiwan provide cases in point (Djankov et al., 2006). In these countries ownership concentration is likely to be an effective substitute for legal protection. By consolidating their interests, investors can prevent expropriation, thus strengthening the association between ownership and performance. Things are different, however, in countries in which shareholders enjoy excellent legal protection. In this study, exemplary countries are Hong Kong, Singapore, and Malaysia (Djankov et al., 2008). In these countries, concentrated owners enjoy little if any special powers over corporate directors and officers, as shareholder interests are firmly protected by relevant laws and an effective judiciary. Under these conditions, concentrated ownership is a redundant corporate governance feature at best. Hence we expect the association between ownership concentration and firm performance to be weaker in the presence of adequate legal protection, due to both the former's redundancy as a governance mechanism and the potential costs of concentrated ownership (see below). Hence Hypothesis 3b:

Hypothesis 3b The association between concentrated ownership and firm performance is negatively moderated by the level of legal protection against self-dealing offered by the firm's home country.

Private benefits of control At its core, the field of corporate governance deals with the distribution of corporate residuals (Shleifer \& Vishny, 1997). Although a perfectly efficient corporate governance regime would distribute the corporate residual over all shareholders in proportion to their economic ownership (La Porta et al., 1999), many existing corporate governance regimes allow for some private benefits of control, that is, a proportion of the residual that is not shared among all shareholders but that is enjoyed exclusively by a controlling shareholder (Dyck \& Zingales, 2004). It is important to note that these private benefits are de facto benefits, which may be obtained in spite of a high level of de jure protection against self-dealing. In some Asian countries, de jure protection clauses can effectively be circumvented by dominant shareholders through corruption or because these 
countries simply lack the capacity to monitor corporate governance and police white collar crime (Claessens \& Fan, 2002).

Asian countries that approach the ideal of a highly efficient corporate governance regime include Hong Kong, Japan, Singapore, and Taiwan (Dyck \& Zingales, 2004), as the private benefits of control in these nations are practically zero. In these contexts, the association between concentrated ownership and firm performance is likely to be stronger (everything else being equal), because there exist fewer opportunities for tunneling practices by those in control (Bertrand et al., 2002; Johnson et al., 2000). ${ }^{2}$ In contrast, the governance regimes of other Asian nations offer controlling shareholders ample opportunities to "take the money and run" (Djankov et al., 2008: 2). Countries in which minority shareholders are consistently expropriated include Korea, the Philippines, and Thailand (Dyck \& Zingales, 2004). Here, the strength of the relationship between concentrated ownership and firm performance is likely to be weaker because controlling shareholders are more likely to succeed in siphoning off corporate wealth into private coffers. See Hypothesis $3 \mathrm{c}$ :

Hypothesis 3c The association between concentrated ownership and firm performance is negatively moderated by the level of private benefits the concentrated owner is allowed to reap by the corporate governance system of the firm's home country.

\section{Methods}

\section{Methodological overview}

We used two groups of meta-analytical procedures to test our Hypotheses. For Hypotheses 1a, 1b, 1c, 2a, and 2b, we used Hedges and Olkin-type meta-analyses (HOMA; Hedges \& Olkin, 1985). In HOMA there are two methods for combining study estimates. The first method utilizes a fixed effects model, which assumes the absence of heterogeneity between study results. In fixed effects HOMA, the collected effect sizes are solely corrected for sampling error, under the assumption that differences in sample size are the sole driver of variability between effect sizes. The second method employs random effects models, and is currently favored by the meta-analytic community (Raudenbush \& Bryk, 2002; Kisamore \& Brannick, 2008). Attractively, random effects HOMA is more conservative than fixed effects HOMA when effect size distributions are heterogeneous, but both methods yield materially similar results when the distribution is homogeneous (Lipsey \& Wilson, 2001). The random effects method assumes that studies are estimating different effect sizes, which are corrected for sampling error plus a value that represents other sources of

\footnotetext{
${ }^{2}$ Note that the absence of private benefits of control in countries with strong legal protection of (minority) shareholders may lead to an absolute undersupply of ownership concentration nevertheless, as private benefits of control are an incentive for owners to concentrate their ownership that at least partially offsets its costs (e.g., suboptimal diversification, a lack of liquidity).
} 
variability, which are in turn assumed to be randomly distributed. In short, we opt for random effect HOMA.

In recent years, so-called artifact-corrected meta-analytic methods (ACMA; Hunter \& Schmidt, 2004) have become more popular than HOMA, especially in psychology and in the management sciences (Eden, 2002). In ACMA, effect sizes are corrected for a much broader array of statistical artifacts, including measurement error, dichotomization, and range restriction. However, since practically all studies in the field of corporate governance are based on independently verifiable economic data rather than on self-reported psychometric data, random effects HOMA is the more appropriate choice for estimating mean effect sizes (Rosenthal, 1991).

To test Hypotheses 3a, 3b, and 3c, we used meta-analytic regression analyses (MARA; Lipsey \& Wilson, 2001). MARA is a special type of weighted least squares (WLS) regression analysis, which is designed specifically to assess the relationship between effect size and moderator variables in order to model previously unexplored heterogeneity in the effect size distribution (Lipsey \& Wilson, 2001). One of the unique benefits of MARA is that it allows for the modeling of such heterogeneity with the help of data that were not part of the primary studies involved. In our case, we collected additional country-level institutional variables to explain heterogeneity across effect sizes.

\section{Sample and coding}

To identify the population of studies that report on the relationship between ownership concentration and firm performance in Asia, we used a set of complementary search strategies, through which we systematically explored both published and unpublished sources. A combinatory search strategy, through which working papers and articles that have previously appeared in books or journals are explored in tandem, improves the scope and validity of a meta-analysis in two ways. First, a combined search maximizes the number of useful studies included in the analysis and therefore minimizes the odds of "missing a useful paper that lies outside one's regular purview" (White, 1994: 44). Second, it helps to overcome the confirmatory bias towards which every meta-analysis drawing on exclusively published sources is prone. In Pfeffer's words: "published results are systematically biased in favor of those showing predicted effects, which in turn means that meta-analyses, which invariably rely mostly if not exclusively on published studies, can easily overestimate actual effect sizes" (2007: 1338). Exploring and including working papers helps alleviate this concern.

In all, we used four different search strategies to uncover relevant published and unpublished works. First, we read several prior review articles (e.g., Becht, Bolton, \& Roell, 2005; Gadhoum, Noiseux, \& Zeghal 2005; Holderness, 2003) and one metaanalysis focusing on the relationship between equity holdings and firm performance in the United States (Dalton et al., 2003). Second, we examined five electronic databases: (1) ABI/INFORM Global, (2) EconLit, (3) Google Scholar, (4) JSTOR, and (5) SSRN, using the following search terms: "blockholder," "equity," "insider ownership," "institutional ownership," "outside ownership," "ownership," and "shareholders." Third, we conducted a manual search of the most relevant journals in the accounting, economics, finance, and management fields. Illustrative examples include: Academy of Management Journal; Corporate Governance: An International Review; Journal of 
Business Finance \& Accounting; Journal of Comparative Economics; Journal of Corporate Finance; Journal of Finance; and Strategic Management Journal. Fourth, upon collecting an initial set of studies, we used the "snowballing" technique in that we searched reference lists for previously unidentified relevant papers. These four strategies yielded a final sample consisting of 290 effect sizes derived from 65 primary studies. In turn, these studies consisted of 49 journal articles, 15 unpublished working papers, and $1 \mathrm{PhD}$ thesis.

We proceeded by reading all articles in the final set and by developing a coding protocol (Lipsey \& Wilson, 2001) for extracting data on all relevant variables. To test Hypotheses 1a, 1b, and 1c, we collected information on effect sizes and sample sizes. To test Hypotheses $2 \mathrm{a}$ and $2 \mathrm{~b}$, we additionally differentiated between "domestic" and "foreign" owners, and classified owners alternatively as "inside," "market," or "stable" investors. Table 1 summarizes definitions for all variables included in this study.

\section{HOMA procedure}

The effect size statistic we used for the HOMA is the Pearson product-moment correlation $r$. This correlation coefficient is an easily interpretable and scale free measure. In case studies reporting different effect size statistics, such as Cohen's standardized means difference measure $d$, we converted them back into an $r$ value using the appropriate formulas (Lipsey \& Wilson, 2001). HOMA procedures assume that effect sizes are normally distributed. However, when the underlying (or true) population value of $r$ differs substantially from zero, the effect size distribution tends to become skewed (Rosenthal, 1991), which complicates the comparison and combining of results. A common remedy to this problem is to apply Fisher's (1928) $\mathrm{Zr}$ transformation to the data, to bring them closer to the normal distribution (Hedges \& Olkin, 1985). In our HOMA we therefore used Fisher's $\mathrm{Zr}$ transformed correlations. $^{3}$

An important question in HOMA is how to deal with studies that contain multiple measurements of the focal effect (Bijmolt \& Pieters, 2001). In our study, multiple measurements of the concentrated ownership - financial performance relationship are often reported due to different simultaneous operationalizations of ownership (e.g., different cut-off points of concentrated ownership) or performance (e.g., both market- and accounting-based measured of performance). At stake is the trade-off between on the one hand stochastic independence of the various effect sizes in the analysis and on the other the use of all available information. A Monte Carlo simulation by Bijmolt and Pieters (2001) shows that procedures using the complete set of measurements outperform those representing each study by only a single value (such as a single best indicator or a composite measure) in areas like parameter significance testing and parameter estimation accuracy. We therefore decided to include all available measurements in our study.

To arrive at an appropriate estimate of the meta-analytic mean, we have to account for differences in precision across effect sizes, as well as for variability in the population of effects. These differences derive from differences in the sample

\footnotetext{
${ }^{3}$ Fisher's $\mathrm{Zr}$ transformed correlations are calculated as follows: $z_{r}=\frac{1}{2} \ln \left(\frac{1+r}{1-r}\right)$, where $r$ is the untransformed correlation coefficient.
} 
Table 1 Description of variables.

Variable
Ownership concentration

Domestic owner

Foreign owner

Inside investor

Market investor

Stable investor

Accounting performance

Market performance

Rule of law
Description

A measure of the degree to which ownership in the firm is concentrated in the hands of a single investor; concentrated ownership refers both to substantial minority shareholders as well as to large shareholders enjoying outright control over the firm. Common cut-off points above which ownership is seen as (highly) concentrated are $10 \%$ and $20 \%$ ownership levels respectively (La Porta et al., 1999)

A variable which assumes a positive value (either " 1 " in case of dummy operationalizations or a percentage in case the degree of ownership concentration is known) when the dominant owner is a domestic party (e.g., a domestic firm, financial institution, business group, or other; see for instance Douma et al., 2006).

A variable which assumes a positive value (either " 1 " in case of dummy operationalizations or a percentage in case the degree of ownership concentration is known) when the dominant owner is a foreign party (e.g., a foreign firm, financial institution, business group, or other; see for instance Douma et al., 2006).

A variable which assumes a positive value (either "1" in case of dummy operationalizations or a percentage in case the degree of ownership concentration is known) when the dominant owner is an insider in the firm (e.g., managers, founders, and their immediate family members; see for instance Gedajlovic et al., 2005).

A variable which assumes a positive value (either " 1 " in case of dummy operationalizations or a percentage in case the degree of ownership concentration is known) when the dominant owner is solely tied to the firm via an arm's length equity stake (e.g., foreign shareholders, pension funds, and investment trusts; see for instance Gedajlovic et al., 2005).

A variable which assumes a positive value (either " 1 " in case of dummy operationalizations or a percentage in case the degree of ownership concentration is known) when the dominant owner is durably tied to the firm via multiple business ties over and above the equity tie (e.g., banks, business partners, or firms that are a member in the same business group; see for instance Gedajlovic et al., 2005).

Any indicator of the financial performance of the firm that is expressed in the form of an accounting-based measure of firm profits (ROA, ROE, ROS, ROI, EPS, and PM).

Any indicator of the financial performance of the firm that is expressed in the form of a market-based measure of firm value (stock returns, market-to-book ratio, Tobin's Q). A variable which measures the extent to which agents have confidence in and abide by the rules of society in 2002 . These include perceptions of the incidence of violent and non-violent crime, the effectiveness and predictability of the judiciary, and the enforceability of contracts (Kaufmann et al., 2005). 
Table 1 (continued).

\begin{tabular}{|c|c|}
\hline Variable & Description \\
\hline Anti-self-dealing index & $\begin{array}{l}\text { A variable which measures the extent to which national } \\
\text { jurisdictions offer minority shareholders protection against } \\
\text { expropriation by controlling shareholders, expressed } \\
\text { in the form of a zero (low protection) to one } \\
\text { (high protection) index. The index includes ex-ante } \\
\text { and ex-post controls around self-dealing transactions } \\
\text { (Djankov et al., 2008). }\end{array}$ \\
\hline Private benefits of control index & $\begin{array}{l}\text { A variable which measures the excess value (over and } \\
\text { above the market value) of a controlling block of shares } \\
\text { as measured in an exchange transaction. This excess value, } \\
\text { which is paid in the form of a "block premium," captures } \\
\text { the discounted future cash flows the acquirer expects to } \\
\text { expropriate from minority shareholders. The block premium } \\
\text { is computed by taking the difference between the price per } \\
\text { share paid for the control block and the exchange price } \\
2 \text { days after the announcement of the control transaction, } \\
\text { dividing by the exchange price and multiplying by the ratio } \\
\text { of the proportion of cash flow rights represented in the } \\
\text { controlling block (Dyck \& Zingales, 2004). }\end{array}$ \\
\hline Publication year & $\begin{array}{l}\text { For journal articles: year in which the article first appeared } \\
\text { in print. For working papers: year in which the paper was } \\
\text { first included in a publicly accessible working paper series. }\end{array}$ \\
\hline Published & $\begin{array}{l}\text { A dummy variable measuring whether a specific study was } \\
\text { published in a scholarly peer reviewed journal (1) or not (0). }\end{array}$ \\
\hline Cross-sectional design & $\begin{array}{l}\text { A dummy variable measuring whether the data included } \\
\text { in a specific study was based on a cross-sectional (1) or } \\
\text { a longitudinal (0) observation plan. }\end{array}$ \\
\hline Ln GDP/capita & $\begin{array}{l}\text { Natural log of per capita gross domestic product in } \\
2003 \text { US dollars (World Development Indicators } \\
\text { at: http://devdata.worldbank.org/dataonline/). }\end{array}$ \\
\hline Stock market capitalization/GDP & $\begin{array}{l}\text { Average of the ratio of stock market capitalization } \\
\text { to gross domestic product for the period 1999-2003 } \\
\text { (World Development Indicators at: http://devdata.worldbank.org/ } \\
\text { dataonline/). }\end{array}$ \\
\hline
\end{tabular}

sizes of the underlying primary studies on which the effect sizes are based, and from a constant term that represents the variability across the population effects. Hedges and Olkin (1985) demonstrated that the optimal measure of precision for a given effect size is the inverse variance weight $w$ : the inverse of the squared standard error value of the effect size. ${ }^{4}$ With the help of these weights, we can subsequently

\footnotetext{
${ }^{4} w$ is calculated as follows: $w_{i}=\frac{1}{s e_{i}^{2}+\hat{v}_{\theta}}$, where SE is the standard error of the effect size and $\widehat{v}_{\theta}$ is the random effects variance component., which is in turn calculated as: s.e. $\left(z_{r}\right)=\frac{1}{\sqrt{n-3}}$, and the formula for random effect variance is: $\widehat{v}_{\theta}=\frac{Q_{T}-k-1}{\sum w-\left(\frac{\sum_{w}{ }^{2}}{\sum_{w}}\right)}$
} 
calculate the meta-analytic mean effect size, its standard error, and the corresponding confidence interval. ${ }^{5}$

\section{MARA procedure}

Variables We used MARA to test Hypotheses 3a, 3b, and 3c. To measure the overall quality of the background institutions in the various Asian jurisdictions in our sample (cf. Hypothesis 3a), we used Kaufmann, Kraay, and Mastruzzi's (2005) oftused "rule of law" measure. We assessed the jurisdictional level of legal protection against self-dealing (cf. Hypothesis 3b) with Djankov et al.'s (2008) "anti-selfdealing index." To estimate the realized benefits of corporate control in Asia (cf. Hypothesis 3c), we used Dyck and Zingales' (2004) "private benefits of control index." We furthermore assessed the influence of three additional methodological moderator variables, to assess whether the observed heterogeneity in the effect size distribution was an artifact of differences in study design and status. Specifically, we assessed whether a particular effect size was derived from: (1) a recent or an older study; (2) from a published or unpublished study; and (3) a study using a crosssectional or a longitudinal observation plan. Finally, we used two control variables to account for any spurious differences in economic development across the nations in our sample: (1) gross domestic product (GDP) per capita, and (2) stock-market capitalization as a fraction of GDP. All variables are summarily described in Table 1.

Analysis We used WLS regression analysis to assess the relationship between effect size and moderator variables (Lipsey \& Wilson, 2001). We use weighted regression to account for differences in precision across the effect sizes included in our study. Research by Hedges (Hedges, 1982; Hedges \& Olkin, 1985) shows that the optimal weight to be used in MARA is again the inverse variance weight $w$. We had to rely on a modified type of WLS, because most statistical analysis programs will provide correct estimates of the regression coefficients, but report incorrect standard errors and significance levels for MARA. This is the case when the software interprets the inverse variance weights as "representing multiple effect sizes rather than weightings of single effect sizes and attributes an exaggerated $n$ to the effect size sample" (Lipsey \& Wilson, 2001: 122). Fortunately, this problem is easy to correct. Hedges and Olkin (1985) demonstrated that a correct standard error can be computed for the unstandardized regression coefficients using the incorrect standard error and the mean-square residual. A significance test (z-test) can then be conducted by dividing the unstandardized regression coefficient by its corrected standard error (Lipsey \& Wilson, 2001). We use these modifications in the analysis presented here.

Meta-analysts have to choose between two estimation options when modeling between-study effect size differences through MARA. The first is to opt for a fixed effects model, in which it is assumed that all between-study differences can wholly

\footnotetext{
${ }^{5}$ The meta-analytic mean is calculated as follows: $\overline{E S}=\frac{\sum(w \times E S)}{\sum w}$, with its standard error: $s e_{\overline{E S}}=$ $\sqrt{\frac{1}{\sum w}}$, and with its $95 \%$ confidence interval computed as: Lower $=\overline{E S}-1.96\left(s e_{\overline{E S}}\right)$, Upper $=$ $\overline{E S}+1.96\left(s e_{\overline{E S}}\right)$.
} 
be attributed to systematic variance (captured by modeled moderator variables) and subject-level sampling error (Lipsey \& Wilson, 2001). But effect size distributions may remain heterogeneous even after modeling for between-study differences. A second option is then to use a mixed-effects model, in which variability in the effect size distribution is again attributed to systematic between-study differences and subject-level sampling error, but in which there is also a remaining unmeasured or even immeasurable random component (Lipsey \& Wilson, 2001). Fixed effects models have more statistical power, but also higher Type I error rates, whereas both statistical power and Type I error rates are lower for mixed-effects models. Since the meta-analysis community is becoming increasingly concerned about the inaccuracy of fixed effects models (personal correspondence with David Wilson), however, we have opted for a more conservative mixed effects specification.

\section{Results}

\section{Hypothesis testing}

Table 2 reports the HOMA results pertaining to Hypotheses 1a, 1b, 1c, 2a, and 2b. Hypothesis $1 \mathrm{~b}$ is rejected in favor of Hypothesis 1a: the mean rho of the relationship between ownership concentration and firm performance is .04 $(k=290)$ and the confidence interval does not include zero (which implies that the effect is significant). This effect is independent of the chosen performance variable, as the

Table 2 Meta-analytic results for the ownership concentration-firm performance relationship.

\begin{tabular}{lrrrrr}
\hline Predictor & $\mathrm{K}$ & $N$ & Mean & $\mathrm{SD}_{\rho}$ & \multicolumn{1}{c}{ CI $95 \%$} \\
\hline Ownership concentration to performance & 290 & 660,087 & 0.04 & 0.01 & $0.03 / 0.05$ \\
Accounting measures & 206 & 546,766 & 0.05 & 0.01 & $0.03 / 0.06$ \\
Market measures & 84 & 113,321 & 0.04 & 0.01 & $0.01 / 0.06$ \\
Domestic owners to performance & 128 & 341,991 & 0.02 & 0.01 & $0.01 / 0.04$ \\
Accounting measures & 89 & 271,744 & 0.02 & 0.01 & $0.01 / 0.04$ \\
Market measures & 39 & 70,247 & 0.02 & 0.02 & $-0.02 / 0.06$ \\
Foreign owners to performance & 46 & 49,474 & 0.15 & 0.02 & $0.11 / 0.19$ \\
Accounting measures & 32 & 35,790 & 0.17 & 0.02 & $0.12 / 0.21$ \\
Market measures & 14 & 13,684 & 0.12 & 0.03 & $0.06 / 0.17$ \\
Market owners to performance & 67 & 68,957 & 0.13 & 0.01 & $0.10 / 0.16$ \\
Accounting measures & 48 & 49,753 & 0.14 & 0.02 & $0.10 / 0.17$ \\
Market measures & 19 & 19,204 & 0.10 & 0.02 & $0.05 / 0.15$ \\
Stable owners to performance & 90 & 346,066 & 0.01 & 0.01 & $-0.00 / 0.02$ \\
Accounting measures & 70 & 302,715 & 0.01 & 0.01 & $-0.00 / 0.03$ \\
Market measures & 20 & 43,351 & -0.00 & 0.01 & $-0.03 / 0.03$ \\
Inside owners to performance & 81 & 117,874 & 0.04 & 0.01 & $0.02 / 0.07$ \\
Accounting measures & 53 & 93,911 & 0.04 & 0.01 & $0.03 / 0.06$ \\
Market measures & 28 & 23,963 & 0.03 & 0.04 & $-0.05 / 0.11$ \\
Ownership concentration to performance & & & & & \\
0\% to 10\% & 62 & 132,754 & 0.09 & 0.01 & $0.06 / 0.11$ \\
10\% to 25\% & 60 & 42,295 & 0.07 & 0.02 & $0.03 / 0.11$ \\
25\% to 50\% & 47 & 177,402 & 0.00 & 0.01 & $-0.02 / 0.03$ \\
50\% to 100\% & 3 & 5,326 & 0.04 & 0.05 & $-0.05 / 0.14$ \\
\hline
\end{tabular}


difference between market- and accounting-based measures of performance is negligible. In short: in the Asian context, ownership concentration enhances corporate performance.

This finding needs to be nuanced in two ways, however. First, the mean effect size we found is small by conventional standards (Cohen, 1977). In other words, ownership concentration improves corporate performance in Asia, but certainly not drastically. Second, and more importantly, the associational strength of the relationship between ownership concentration and corporate performance varies significantly across contexts. Cochran's (1954) $Q$ test, the most common test to assess whether there is true heterogeneity in a meta-analysis, is highly significant $(Q=4301.22 ; p<0.001){ }^{6}$

Table 3 reports the country-specific HOMA results. The results reported in Table 2 derive from eleven Asian countries, but we were unable to identify a sufficient number of studies from Indonesia and the Philippines to conduct countryspecific analyses. Of the remaining nine countries, the effect of ownership concentration on performance was positive and significant in four cases: India, Japan, South Korea, and Taiwan. In these contexts, concentrated ownership clearly matters for performance, with the mean effect sizes for the focal relationship ranging from .04 (Japan) to .12 (Taiwan). In four other nations - China, Malaysia, Singapore, and Thailand - no significant performance effects of concentrated ownership could be identified. In these countries, concentrated ownership does not bolster corporate performance (Hong Kong is a boundary case, for which the focal effect is modest (.02) and barely significant). Below, we will explore the institutional origins of these differences.

Hypothesis $1 \mathrm{c}$ is confirmed. Even though in the aggregate the positive effects of concentrated ownership on firm performance prevail in the Asian context, the effect is not a monotonous function of the level of ownership. At lower levels of ownership, where owners can influence managers but lack full control over the firm, the effect on performance is relatively strong and significant $(0 \%-10 \%$ : mean rho $=.09 ; 10 \%-$ $25 \%$ : mean rho=.07). As the ownership stake increases $(25 \%-50 \%)$, such that owners can exert full control over the firm (usually with the help of pyramidal equity schemes), the effect on performance becomes negligible (mean rho=.01) and insignificant. We conjecture that at these intermediate levels of concentrated ownership, the positive effects to firms of having a concentrated owner are offset by increased opportunities for self-dealing (see also below). At even higher levels of ownership $(50 \%-100 \%)$ the effect on performance increases again (mean rho $=.04)$, but remains insignificant. In sum, performance is non-monotonically related to ownership.

Hypothesis $2 \mathrm{a}$ is fully confirmed by the HOMA results, lending credence to the emerging insight in the corporate governance literature that the identity of the concentrated owner matters for corporate performance. Whereas the presence of a domestic concentrated owner does not lead to marked improvements in terms of performance (mean rho=.02), having a foreign concentrated owner "on board"

\footnotetext{
${ }^{6}$ The $Q$ test is computed by summing the squared deviations of each study's effect estimate from the overall effect estimate (Cochran, 1954). In this exercise, each study is weighted by its $w$. The $Q$ test assumes homogeneity, following a Chi-square distribution with $k-1$ degrees of freedom $(k=$ the number of studies). When $Q$ is significant, as it is in our case, the assumption of homogeneity is rejected.
} 
Table 3 Country-specific meta-analytic results.

\begin{tabular}{|c|c|c|c|c|c|c|}
\hline Country & Predictor & $\mathrm{K}$ & $N$ & Mean & $\mathrm{SD}_{\rho}$ & CI 95\% \\
\hline \multirow[t]{4}{*}{ China } & Ownership to performance & 33 & 87,488 & 0.02 & 0.02 & $-0.03 / 0.06$ \\
\hline & Market owners to performance & - & - & - & - & - \\
\hline & Stable owners to performance & 17 & 46,006 & -0.03 & 0.02 & $-0.07 / 0.00$ \\
\hline & Inside owners to performance & 9 & 9,168 & 0.10 & 0.10 & $-0.09 / 0.29$ \\
\hline \multirow[t]{4}{*}{ Hong Kong } & Ownership to performance & 32 & 46,052 & 0.02 & 0.01 & $0.00 / 0.03$ \\
\hline & Market owners to performance & 3 & 6,318 & 0.02 & 0.02 & $-0.02 / 0.07$ \\
\hline & Stable owners to performance & 3 & 6,318 & 0.02 & 0.03 & $-0.04 / 0.07$ \\
\hline & Inside owners to performance & 6 & 12,636 & 0.02 & 0.02 & $-0.01 / 0.05$ \\
\hline \multirow[t]{4}{*}{ India } & Ownership to performance & 24 & 14,979 & 0.06 & 0.02 & $0.02 / 0.09$ \\
\hline & Market owners to performance & 14 & 8,607 & 0.08 & 0.03 & $0.03 / 0.13$ \\
\hline & Stable owners to performance & 4 & 342 & -0.05 & 0.05 & $-0.15 / 0.06$ \\
\hline & Inside owners to performance & 3 & 2,098 & 0.02 & 0.04 & $-0.06 / 0.09$ \\
\hline \multirow[t]{4}{*}{ Japan } & Ownership to performance & 62 & 374,610 & 0.04 & 0.01 & $0.02 / 0.06$ \\
\hline & Market owners to performance & 15 & 15,361 & 0.16 & 0.04 & $0.09 / 0.24$ \\
\hline & Stable owners to performance & 24 & 233,016 & 0.02 & 0.01 & $-0.01 / 0.04$ \\
\hline & Inside owners to performance & 4 & 47,206 & 0.04 & 0.03 & $-0.01 / 0.09$ \\
\hline \multirow[t]{4}{*}{ Malaysia } & Ownership to performance & 11 & 9,943 & 0.02 & 0.03 & $-0.03 / 0.07$ \\
\hline & Market owners to performance & 2 & 292 & 0.19 & 0.06 & $0.08 / 0.31$ \\
\hline & Stable owners to performance & - & - & - & - & - \\
\hline & Inside owners to performance & 5 & 6,095 & -0.05 & 0.03 & $-0.11 / 0.01$ \\
\hline \multirow[t]{4}{*}{ Singapore } & Ownership to performance & 21 & 51,590 & 0.01 & 0.01 & $-0.01 / 0.04$ \\
\hline & Market owners to performance & 6 & 11,430 & -0.00 & 0.02 & $-0.05 / 0.03$ \\
\hline & Stable owners to performance & 8 & 11,746 & 0.03 & 0.02 & $0.00 / 0.07$ \\
\hline & Inside owners to performance & 4 & 532 & -0.06 & 0.04 & $-0.15 / 0.02$ \\
\hline \multirow[t]{4}{*}{ South Korea } & Ownership to performance & 53 & 41,674 & 0.06 & 0.01 & $0.04 / 0.08$ \\
\hline & Market owners to performance & 17 & 21,875 & 0.14 & 0.02 & $0.10 / 0.19$ \\
\hline & Stable owners to performance & 14 & 34,771 & 0.03 & 0.01 & $0.00 / 0.05$ \\
\hline & Inside owners to performance & 12 & 17,027 & 0.02 & 0.01 & $0.00 / 0.04$ \\
\hline \multirow[t]{4}{*}{ Taiwan } & Ownership to performance & 37 & 13,182 & 0.12 & 0.02 & $0.08 / 0.16$ \\
\hline & Market owners to performance & 7 & 1,230 & 0.27 & 0.03 & $0.22 / 0.33$ \\
\hline & Stable owners to performance & 10 & 2,280 & 0.04 & 0.03 & $-0.02 / 0.10$ \\
\hline & Inside owners to performance & 18 & 9,582 & 0.13 & 0.02 & $0.08 / 0.18$ \\
\hline \multirow[t]{4}{*}{ Thailand } & Ownership to performance & 5 & 5,424 & -0.02 & 0.05 & $-0.10 / 0.07$ \\
\hline & Market owners to performance & - & - & - & - & - \\
\hline & Stable owners to performance & - & - & - & - & - \\
\hline & Inside owners to performance & - & - & - & - & - \\
\hline
\end{tabular}

makes a considerable positive difference (mean rho=.15). Hypothesis $2 \mathrm{~b}$ is also confirmed, as market investors (mean rho $=.13$ ) strongly outperform stable (mean rho $=.01$, n.s.) and inside (mean rho $=.04)$ owners.

Again, the results for Hypothesis $2 \mathrm{~b}$ are nuanced somewhat by the comparative analysis (cf. Table 3). Of the seven countries for which we have sufficient data, the pattern predicted by Hypothesis $2 b$ is clearly found in five cases: India, Japan, Malaysia, South Korea, and Taiwan. In two instances (notably, Hong Kong and Singapore), however, no significant differences could be noted between the various types of owners. We return to this issue in the discussion section of this paper, where we shall offer an institutional explanation for these noted differences.

Table 4 shows the MARA results for Hypotheses 3a, 3b, and 3c. The model fits the data reasonably well $\left(R^{2}=.22\right)$. More importantly, the homogeneity statistic $Q$ is significant for the modeled variance in effect sizes $(p<.01)$, implying that the model 
Table 4 Results of mixed effects WLS regression. ${ }^{\mathrm{a}}$

${ }^{\text {a } U n s t a n d a r d i z e d ~ r e g r e s s i o n ~}$ coefficients are presented for study moderators and substantive moderators with standard errors in parentheses $k$ is the total number of effect sizes; $Q$ is the homogeneity statistic with its probability in parentheses; $v$ is the random effects variance component

$* p<0.1$

$* * p<0.05$

$* * * p<0.01$

\begin{tabular}{ll}
\hline Variable & Model \\
\hline Publication year & $0.00(0.00)$ \\
Published & $-0.20(0.07)^{* *}$ \\
Cross-sectional design & $0.02(0.02)$ \\
Rule of law & $0.74(0.35)^{* *}$ \\
Anti-self-dealing index & $-1.43(0.62)^{* *}$ \\
Private benefits of control & $-0.99(0.31)^{* *}$ \\
Gross domestic product & $-0.54(0.25)^{*}$ \\
Stock market capitalization & $0.00(0.00)^{* *}$ \\
$R^{2}$ & 0.2183 \\
$K$ & 235 \\
$Q_{\text {Model }}(p)$ & $46.60(0.00)$ \\
$Q_{\text {Residual }}(p)$ & $166.88(0.14)$ \\
$V$ & 0.00468 \\
\hline
\end{tabular}

adequately captures the heterogeneity present in the effect size distribution. The insignificant $Q$ value for the residual variance $(p>.10)$ shows that the assumptions for mixed-effects MARA are met and that there is no need for further moderator analysis (Lipsey \& Wilson, 2001).

The results confirm Hypothesis 3a. The overall quality of a given Asian nation's background institutions, as captured by the rule of law variable (Kaufmann et al., 2005), positively moderates the relationship between concentrated ownership and firm performance $(p<.05)$. In other words, the effectiveness of ownership concentration as a corporate governance strategy is to some degree contingent upon the overall quality of the institutional matrix in a given jurisdiction (North, 1990; Shleifer \& Vishny, 1997). Hence there can be seen to be institutional complementarity between the quality of a nation's background institutions as measured by the rule of law variable, on the one hand, and the effectiveness of ownership concentration as one of two generic corporate governance strategies, on the other. Hypothesis $3 \mathrm{~b}$ is also confirmed. The degree of protection against self-dealing transactions by directors a given jurisdiction offers to its shareholders (Djankov et al., 2008) negatively moderates our focal relationship $(p<.05)$. In other words, within Asian corporate governance configurations, legal protection of shareholders and concentrated ownership are substitutes rather than complements. Finally, the results also confirm Hypothesis 3c. The extent to which private benefits of control can de facto be enjoyed by controlling shareholders (Dyck \& Zingales, 2004) ${ }^{7}$ negatively moderates the concentrated ownership — corporate performance relationship $(p<.05)$. Apparently, when jurisdictions adopt a lenient stance towards the expropriation of minority shareholders by controlling parties, the potential gains of ownership concentration as a generic corporate governance strategy are offset by the costs that result from private benefits of control (Bertrand et al., 2002; Johnson et al., 2000).

\footnotetext{
${ }^{7}$ Such de facto granted private benefits of control are not simply the inverse of the de jure restrictions on self-dealing in a given Asian jurisdiction, as the rather modest bivariate correlation (-.30) between the antiself-dealing index (Djankov et al., 2008) and the private benefits of control index (Dyck \& Zingales, 2004) across the countries in our sample shows. This finding illustrates that the adoption of restrictions on selfdealing, which are often "transplanted" into Asian legal systems from Western origins (La Porta et al., 1998), need not lead to their actual implementation and enforcement.
} 
Robustness checks and control variables

In order to assess the generalizability of our findings, we conducted two robustness tests. ${ }^{8}$ First, we have to account for the fact that the Japanese economy is very large relative to the other economies in the region, and that Japan has attracted a disproportionate amount of attention by researchers. As a consequence, a significant number of our harvested effect sizes (62 out of 290) and the majority of the underlying observations $(374,610$ out of 660,087$)$ derive from the Japanese context. To assess whether the Japanese data points biased our research findings, we created a separate dummy variable, coded as " 1 " in case a harvested effect size represented Japanese data and "0" otherwise, and entered it in a separate MARA analysis. The addition of this variable did not significantly affect our results: the model fit statistics remained within the same order of magnitude, and all three hypothesized effects remained significant. In combination with the finding that the overall effect of concentrated ownership on performance is exactly the same for Japan (.04; see Table 3 ) as for our sample in its entirety (.04; see Table 2$)$, we can conclude that the preponderance of Japanese data did not bias our results.

Second, during the window of observation that is covered in our study, the Asian region was in considerable flux. For example, GNP per capita went up rapidly in many emerging economies, and several countries reformed their minority shareholder protection regimes in the years following the 1997-1998 financial crisis (e.g., see Heugens \& Otten, 2007). These temporal dynamics might possibly have affected our findings, especially since some contributors have suggested that minority shareholder expropriation is more prevalent during times of crisis than during business-as-usual periods (Johnson et al., 2000). We therefore split our overall sample of 290 effect sizes up in four sub-groups, notably: effect sizes covering the pre-crisis period (1996 and before; 83 effects); the crisis period (1997 and 1998; 29 effects); the post-crisis period (1999 and after; 88 effects); and the "mixed" category of studies covering two or more of these periods (90 effects). We then conducted a separate HOMA analysis on each sub-group. All sub-group mean effect sizes did not deviate significantly from the overall mean effect size. In other words, the relationship between concentrated ownership and firm performance varies between jurisdictions (see Table 3), but it is persistent over time.

Table 4 also reports the MARA results for our control variables. No significant effect was found for publication year, implying that the results we found for our focal relationship are stable over time. This corroborates the aforementioned sub-group HOMA results. Interestingly, the published variable was strongly significant and negative, which means that our results are unlikely to be affected by the most common form of publication bias, notably: the retrieved effect size-increasing effect of confirmatory publication bias (Pfeffer, 2007). The cross-sectional design variable came out insignificant, implying that the choice between cross-sectional and longitudinal research designs does not critically influence the outcome of the study for the precise research question we are addressing. Furthermore, the effect of gross domestic product on our focal relationship was significant and negative, implying that

\footnotetext{
${ }^{8}$ We thank APJM Guest Editor Michael Carney for pointing out these two possible boundary conditions to our findings.
} 
the benefits of concentrated ownership are somewhat more pronounced in emerging markets than in mature economies (Stiglitz, 1994). Finally, the effect of stock market capitalization was significant and positive. Apparently, it is easier for concentrated owners to realize better performance in more liquid markets, presumably because liquidity mitigates the costs of concentrated ownership (Maug, 1998).

\section{Discussion}

Concentrated ownership in Asia

The first question we sought to address in this paper was whether firms with concentrated owners outperform firms lacking such owners in the Asian context. Overall, we found a modest (.04) but positive and significant effect for our focal relationship. These results differ from those of another recent meta-analysis by Dalton and his colleagues (Dalton et al., 2003), who found a series of less consequential effects of ownership structure on performance. Our findings are not, however, wholly irreconcilable with those reported in Dalton et al. (2003). In fact, this latter study offers an important starting point for explaining the differences in associational strength of our focal relationship which we found across the various Asian nations in our sample (see Table 3).

The key to understanding Dalton et al.'s (2003) findings is the realization that most of the effect sizes in their study derive from a national context in which shareholders rights are legally well-protected (i.e., the US). Since shareholders in the US can rely on highly liquid equity markets, an active market for corporate control, strong legal protections for shareholders, and highly effective background institutions and judiciary, concentrated ownership does not seem to add any additional benefits in that particular corporate governance configuration. Correspondingly, we also find nonsignificant effects for our focal relationship in countries where minority shareholders' rights are well-protected (i.e., in Hong Kong and Singapore). These findings are fully compatible with those of Dalton et al. (2003).

In contrast, in countries where shareholder protection is historically weak-such as in India or Taiwan - the positive effects of concentrated ownership on firm performance are hard to deny. In these jurisdictions, investors must concentrate their shareholdings in order to privately enforce their interests when external (public) institutions offer little recourse (Khanna \& Palepu, 1997). This finding must be qualified in one important way, however. Our study also shows that ownership concentration becomes less effective as the rule of law becomes weaker (see Table 4). In other words, ownership concentration as a generic corporate governance strategy in Asia is complementary to certain background institutions that offer investors some minimal degree of protection. Where weak ownership protection goes hand-in-hand with weak rule of law-such as in the case of China-even ownership concentration ceases to be an effective corporate governance strategy.

Owner identity in Asia

The second question addressed in this paper was whether the identity of the concentrated owner matters for the performance of Asian firms. The short answer to 
this question is that it does. Foreign owners outperform domestic owners (as predicted by Hypothesis 2a), while market investors outperform stable owners and inside owners (as predicted by Hypothesis $2 b$ ). Yet especially the latter finding appears to be influenced by inter-jurisdictional differences. The pattern predicted by Hypothesis $2 \mathrm{~b}$ holds for India, Japan, Malaysia, South Korea, and Taiwan, but not for Hong Kong and Singapore. What drives these differences?

One way of addressing this question is to explore the correlational "spread" between what the firms controlled by sophisticated market investors can accomplish in a given jurisdiction, on the one hand, and the performance of firms controlled by stable investors (Gedajlovic et al., 2005; Gerlach, 1992), on the other. This spread is bound to be large in markets offering weak minority protection, because stable investors will cream off residual returns via self-dealing transactions or intergroup profit redistribution practices (Gedajlovic \& Shapiro, 2002). In markets with strong protection, in contrast, the spread is likely to be minimal as stable investors are denied tunneling opportunities. In these jurisdictions, the only effective actions stable investors can undertake to increase their private wealth is prompting firm managers to increase performance, which is bound to benefit all shareholders of the firm and not just stable investors. These intuitions can straightforwardly be tested by regressing the market owner/stable owner correlational spread onto the best-available comparative measure for minority shareholder protection: Djankov et al.'s (2008) anti-self-dealing index. See Figure 1.

The results of this exercise are telling. The fit of this univariate model is excellent $\left(R^{2}=.73\right.$ ), implying that the legal protection of (minority) shareholders is the main driver of the manifested differences in associational strength of our focal relationship between owner types across national contexts. This finding has important implications for our second research question. Owner identity does matter to the performance of closely-held Asian firms, but only in jurisdictions that offer weak minority protection. Here, differentially constituted and motivated owners have the opportunity to manipulate the firms they own to pursue their own interests. Thus, while market investors will prompt their firms towards better financial performance, stable owners will use their firms as vehicles for business group support and private wealth creation. In jurisdictions where minority protection is stronger, concentrated owners have fewer opportunities to cater to their private needs. In these contexts, the legal system represents an important constraint on organizational design, implying that owners of

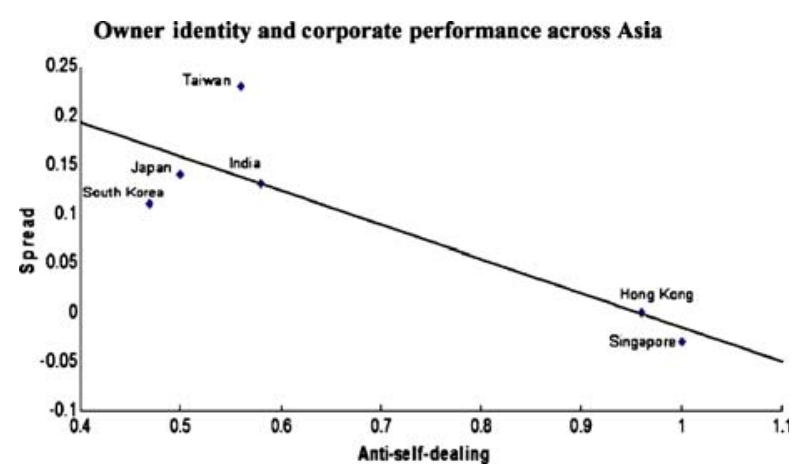

Figure 1 Owner identity and corporate performance across Asia 
all types can only increase their private wealth by adopting strategies that are likely to benefit all shareholders simultaneously. Hence, where the legal protection of minority shareholders is strong, owner identity ceases to be a variable that influences the associational strength of the concentrated ownership-corporate performance relationship.

Institutions and ownership concentration in Asia

The third question this paper sought to address was whether jurisdiction-level institutional features moderate the relationship between concentrated ownership and firm performance in Asia. Corporate governance scholars have long tried to stress the commonalities of the various corporate governance regimes across Asia, in search of an overarching "Asian" model of corporate control, and thus neglecting the influence of differences across national corporate governance regimes (Peng \& Jiang, 2006). In international comparisons, the corporate governance regimes of three nations in particular have attracted the bulk of scholarly attention: the United States, Germany, and Japan. All too often, the specificities of these three corporate governance regimes have been mistakenly taken to be generic properties of the larger geo-political context in which these nations are embedded. Thus scholars often analyze corporate governance regimes through the respective lenses of an "Anglo-American shareholder model," a "continental European stakeholder model," and an "Asian relational model." This paper does not deal with the Anglo-American or continental European worlds, so we will not elaborate on those cases. Our paper does show, however, that Japan's corporate governance system is by no means a generic mold after which all other Asian systems are shaped. Instead, different corporate governance configurations co-exist in the Asian context, and the Japanese way of governing firms is at best "merely" one configuration within this set.

As seen from one point of view, Japan is representative of a sub-set of Asian nations in which the legal protection of minority shareholders is relatively poorly developed, and in which dedicated market investors can reap a considerable performance premium over multiply tied stable investors (i.e., India, South Korea, and Taiwan; see Figure 1). Yet, seen from a different angle, Japan can also be seen as a representative of a group of nations in which de facto expropriation of minority shareholders is next to impossible, due to the fact that the relevant matrix of more generic background institutions is very well-developed (i.e., Hong Kong and Singapore; cf. Dyck \& Zingales, 2004; and Kaufmann et al., 2005).

Our institutional perspective on ownership concentration in Asia thus suggests that there are three dominant corporate governance configurations in this region. First, there is the "high minority protection/high rule of law" cluster (including Hong Kong and Singapore), in which the tunneling problem is not a major factor for the majority of listed firms ${ }^{9}$ and in which there is not much difference between what

\footnotetext{
${ }^{9}$ This observation does not hold for all firms listed on the Hong Kong Stock Exchange (HKEX), however. Due to the absence of legal extraterritoriality, Hong Kong's strict rules regarding protection for minority investors do not apply in mainland China and mainland firms listed on HKEX (which account for some 35 percent of the value of the HKEX's capitalization). Thus, the decisions of Hong Kong courts are not enforceable in China. Significant expropriation of minority shareholders via tunneling is the result (Cheung et al., 2005). We thank APJM Guest Editor Michael Carney for drawing our attention to this point.
} 
market and stable investors can accomplish in terms of firm performance. Second, there is the "low minority protection/fair rule of law" cluster (including South Korea, India, and Taiwan), in which the tunneling problem is prevalent, but in which there is also a considerable difference between the expected returns of market and stable investors, as the former can enforce their rights via the regular court system. Third, there is the "low minority protection/low rule of law" cluster (including China and the Philippines), in which not only the tunneling problem is severe, but in which there is also no "spread" between market and stable investors, as the former cannot rely on working background institutions to enforce their rights. Seen from this perspective, Japan is in fact not representative for the Asian region at all, but is in fact a difficult-to-rubricate hybrid of clusters one and two.

\section{Conclusion}

What have we learned about ownership concentration in Asia? The results reported in this paper have generated at least three new insights into this phenomenon. First, although this paper confirmed that ownership concentration matters in the Asian context, it was found that Asian nations differ markedly in the degree to which ownership concentration is an effective remedy against familiar agency problems. In countries where legal protection of shareholders is mostly lacking, concentrated ownership can have a profoundly positive impact on corporate performance. Yet where legal protection is well-developed, shareholders can rely on a configuration of mostly external corporate governance mechanisms to protect their investments and assure a reasonable return on these investments. Ownership concentration becomes more or less redundant in these contexts, and may even be associated with certain costs, such as: suboptimal risk diversification and lower liquidity. Hence this paper has shown that the two broad corporate governance strategies of ownership concentration and relying on external governance mechanisms (e.g., Gillan, 2006) should be seen as substitutes, not as complements (Aoki, 2001; Hollingsworth \& Boyer, 1997).

Second, this paper has shown that a certain degree of institutional development, as measured by the rule of law variable, is a necessary condition for the broad corporate governance strategy of ownership concentration to work. We found evidence of institutional complementarity between ownership concentration on the one hand, and a threshold level of institutional development that secures the rule of law in a given jurisdiction on the other.

Third, this paper has demonstrated that the identity of the concentrated owner matters in quite a number of Asian jurisdictions. Only a very select set of nationsnotably, Hong Kong and Singapore - are able to sufficiently remedy shareholdermanager and shareholder-shareholder agency problems by predominantly legal means. In most other Asian nations, different kinds of concentrated owners will have differential effects on corporate financial performance. Finally, by unpacking various institutional influences on the effectiveness of concentrated ownership as a governance strategy across 11 Asian jurisdictions, we have contributed to what Peng and Jiang (2006) call an emerging "cross-country, institution-based" theory of corporate governance that provides a more fine-grained account of the costs and benefits of concentrated ownership in Asia. 
Open Access This article is distributed under the terms of the Creative Commons Attribution Noncommercial License which permits any noncommercial use, distribution, and reproduction in any medium, provided the original author(s) and source are credited.

\section{References}

All studies marked an asterisk are included in the meta-analysis.

Abegglen, J. C., \& Stalk, G. 1985. Kaisha: The Japanese corporation. New York: Basic Books.

Aguilera, R. V., \& Jackson, G. 2003. The cross-national diversity of corporate governance: Dimensions and determinants. Academy of Management Review, 28: 447-465.

Alchian, A. A., \& Demsetz, H. 1972. Production, information costs, and economic organization. American Economic Review, 62: 777-795.

*Ang, J. S., \& Ding, D. K. 2006. Government ownership and the performance of government-linked companies: The case of Singapore. Journal of Multinational Financial Management, 16: 64-88.

Aoki, M. 2001. Toward a comparative institutional analysis. Cambridge, MA: MIT Press.

Bae, K.-H., Kang, J.-K., \& Kim, J.-M. 2002. Tunneling or value added? Evidence from mergers by Korean business group. Journal of Finance, 57: 2695-2740.

Bebchuk, L. A. 2007. The myth of the shareholder franchise. Virginia Law Review, 93(3): 675-732.

Bebchuk, L. A., Kraakman, R., \& Trianis, G. 2000. Stock pyramids, cross-ownership, and dual class equity. In R. K. Morck (Ed.). Concentrated corporate ownership, NBER Conference Report Series, Chicago: University of Chicago Press.

Becht, M., Bolton, P., \& Roell, A. 2005. Corporate governance and control, (working paper).

Bertrand, M., Mehta, P., \& Mullainathan, S. 2002. Ferreting out tunneling: An application to Indian business groups. Quarterly Journal of Economics, 117: 121-148.

Bijmolt, T. H. A., \& Pieters, R. G. M. 2001. Meta-analysis in marketing when studies contain multiple measurements. Marketing Letters, 12: 157-169.

*Black, B. S., Jang, H., \& Kim, W. 2006. Predicting firms' corporate governance choices: Evidence from Korea. Journal of Corporate Finance, 12: 660-691.

Bolton, P., \& von Thadden, E. 1998. Blocks, liquidity, and corporate control. The Journal of Finance, 53 (1): $1-25$.

Brickley, J. A., Lease, R. C., \& Smith, C. W. 1988. Ownership structure and voting on antitakeover amendments. Journal of Financial Economics, 20(1-2): 267-291.

Carney, M., \& Gedajlovic, E. R. 2001. Corporate governance and firm capabilities: A comparison of managerial, alliance, and personal capitalisms. Asia Pacific Journal of Management, 18: 335-354.

*Carney, M., \& Gedajlovic, E. R. 2002. The coupling of ownership and control and the allocation of financial resources: Evidence from Hong Kong. Journal of Management Studies, 39: 123-146.

*Chang, E. C., \& Wong, S. M. L. 2004. Political control and performance in China's listed firms. Journal of Comparative Economics, 32: 617-636.

*Chang, J. J., \& Shin, H.-H. 2006. Governance system effectiveness following the crisis: The case of Korean business group headquarters. Corporate Governance: An International Review, 14: 85-97.

*Chang, J. J., \& Shin, H.-H. 2007. Family ownership and performance in Korean conglomerates. PacificBasin Finance Journal, 15: 329-352.

*Chang, S. J. 2002. Ownership structure, expropriation, and performance of group-affiliated companies in Korea (working paper).

*Chau, G., \& Leung, P. 2006. The impact of board composition and family ownership on audit committee formation: Evidence from Hong Kong. Journal of International Accounting, Auditing and Taxation, 15: 1-15.

*Chen, C. J. P., \& Jaggi, B. 2000. Association between independent non-executive directors, family control and financial disclosures in Hong Kong. Journal of Accounting and Public Policy, 19: 285-310.

*Chen, E.-T., \& Nowland, J. 2007. Optimal monitoring in family-owned companies? Evidence from Asia (working paper).

*Chen, K. Y., Elder, R. J., \& Hsieh, Y.-M. 2005. Corporate governance and earnings management: The implications of corporate governance best practice principles for Taiwanese listed companies (working paper). 
*Cheng, S., \& Firth, M. 2005. Ownership, corporate governance and top management pay in Hong Kong. Corporate Governance: An International Review, 23: 291-302.

*Cheung, Y.-L., Connelly, J. T., \& Limpaphayom, P. 2007. Do investors really value corporate governance? Evidence from the Hong Kong market. Journal of International Financial Management and Accounting, 18: 86-122.

*Cheung, Y.-L., Stouraitis, A., \& Wong, A. W. S. 2005. Ownership concentration and executive compensation in closely held firms: Evidence from Hong Kong. Journal of Empirical Finance, 12: 511-532.

Chibber, P. K., \& Majumdar, S. K. 1999. Foreign ownership and profitability: Property rights, control, and the performance of firms in Indian industry. Journal of Law and Economics, 42: 209-238.

*Cho, D.-S., \& Kim, J. 2007. Outside directors, ownership structure and firm profitability in Korea. Corporate Governance: An International Review, 15: 239-250.

*Choi, J. J., \& Park, S. W. 2005. Do outside directors enhance firm performance? Evidence from an emerging market (working paper).

*Choi, J. J., \& Yoo, S. 2005. Foreign equity investment and firm performance (working paper).

*Choi, S., \& Hasan, I. 2005. Ownership, governance, and bank performance: Korean experience. Financial Markets, Institutions \& Instruments, 14: 215-241.

*Chu, E. Y. 2007. Ownership structure, financial rent and performance: Evidence from the Malaysian manufacturing sector. Advances in Financial Economics, 12: 165-202.

*Chung, K. H., \& Kim, J.-K. 1999. Corporate ownership and the value of a vote in an emerging market. Journal of Corporate Finance, 5: 35-54.

*Chung, R., Ho, S., \& Kim, J.-B. 2004. Ownership structure and the pricing of discretionary accruals in Japan. Journal of International Accounting, 15: 1-20.

Claessens, S., Djankov, S., \& Klapper, L. 2003. Resolution of corporate distress in East Asia. Journal of Empirical Finance, 10: 199-216.

Claessens, S., Djankov, S., \& Lang, L. 2000. The separation of ownership and control in East Asian corporations. Journal of Financial Economics, 58: 81-112.

Claessens, S., \& Fan, J. P. H. 2002. Corporate governance in Asia: A survey. International Review of Finance, 3: 71-103.

Cochran, W. G. 1954. The combination of estimates from different experiments. Biometrics, 10: 101-129.

Coffee, J. 1991. Liquidity versus control: The institutional investor as corporate monitor. Columbia Law Review, 91(6): 1277-1368.

Cohen, J. 1977. Statistical power analysis for the behavioral sciences (revised ed.). New York: Academic Press.

Dalton, D., Daily, C., Certo, S., \& Roengpitya, R. 2003. Meta-analysis of financial performance and equity: Fusion or confusion? Academy of Management Journal, 46: 13-26.

*David, P., Hitt, M. A., \& Liang, T. W. 2007. The benefits and costs of large block ownership before and during the East-Asian crisis (working paper).

David, P., Kochhar, R., \& Levitas, E. 1998. The effect of institutional investors on the level and mix of CEO compensation. Academy of Management Journal, 41(2): 200-208.

* David, P., Yoshikawa, T., \& Oyanagi, K. Executive pay and succession in Japan: Divergent effect of foreign and domestic ownership (working paper).

* David, P., Yoshikawa, T., \& Rasheed, A. A. Strategic investments in Japanese corporations: Do foreign portfolio owners foster underinvestment or appropriate investment? (working paper).

Davis, G. F. 2005. New directions in corporate governance. Annual Review of Sociology, 31: 143-162.

*Delios, A., \& Wu, Z. J. 2005. Legal person ownership, diversification strategy and firm profitability in China. Journal of Management and Governance, 9: 151-169.

Demsetz, H., \& Lehn, K. 1985. The structure of corporate ownership: Causes and consequences. Journal of Political Economy, 93: 1155-1177.

Demsetz, H., \& Villalonga, B. 2001. Ownership structure and corporate performance. Journal of Corporate Finance, 7: 209-233.

Denis, K. D., \& McConnell, J. J. 2003. International corporate governance. Journal of Financial and Quantitative Analysis, 38: 1-30.

*Ding, Y., Zhang, H., \& Zhang, J. 2007. Private vs. state ownership and earnings management: Evidence from Chinese listed companies. Corporate Governance: An International Review, 15: 223-238.

Djankov, S., \& Hoekman, B. 2000. Foreign investment and productivity growth in Czech enterprises, World Bank Economic Review, 14: 49-64.

Djankov, S., La Porta, R., López-de-Silanes, F., \& Shleifer, A. 2008. The law and economics of selfdealing. Journal of Financial Economics (forthcoming). 
*Douma, S., George, R., \& Kabir, R. 2006. Foreign and domestic ownership, business groups, and firm performance: Evidence from a large emerging market. Strategic Management Journal, 27: 637-657.

Dyck, A., \& Zingales, L. 2004. Private benefits of control: An international comparison. Journal of Finance, 59: 537-600.

Easterbrook, F. H., \& Fishel, D. R. 1991. The economic structure of corporate law. Cambridge, MA: Harvard University Press.

Eden, D. 2002. From the editors: Replication, meta-analysis, scientific progress, and $A M J$ 's publication policy. Academy of Management Journal, 45: 841-846.

*Eng, L. L., \& Mak, Y. T. 2003. Corporate governance and voluntary disclosure. Journal of Accounting and Public Policy, 22: 325-345.

*Faccio, M., \& Sengupta, R. 2006. Corporate response to distress: Evidence from the Asian financial cisis. Federal Reserve Bank of St. Louis (working paper).

Fama, E. F., \& Jensen, M. C. 1983. Separation of ownership and control. Journal of Law and Economics, 26: $301-325$.

*Filatotchev, I., Lien, Y.-C., \& Piesse, J. 2005. Corporate governance and performance in publicly listed, family-controlled firms: Evidence from Taiwan. Asia Pacific Journal of Management, 22: 257-283.

*Firth, M., Fung, P. M. Y., \& Rui, O. M. 2007. Ownership, two-tier board structure, and the informativeness of earnings: Evidence from China. Journal of Accounting and Public Policy, 26: 463-496.

Fisher, R. A. 1928. Statistical methods for research workers (2nd ed.). London: Oliver \& Boyd.

Friedman, E., Johnson, S., \& Mitton, T. 2003. Propping and tunneling. Journal of Comparative Economics, 31: 732-750.

Fukao, M. 1999. Japanese financial instability and weakness in the corporate governance structure. Paris: OECD.

Gadhoum, Y., Noiseux, M.-H., \& Zeghal, D. 2005. Demystifying the illusion of the positive effect of ownership concentration on corporate performance (working paper).

*Gedajlovic, E., \& Shapiro, D. 2002. Ownership and firm profitability in Japan. Academy of Management Journal, 45: 575-585.

*Gedajlovic, E., Shapiro, D., \& Buduru, B. 2003. Financial ownership, diversification and firm profitability in Japan. Journal of Management and Governance, 7: 315-335.

*Gedajlovic, E., Yoshikawa, T., \& Hashimoto, M. 2005. Ownership structure, corporate strategy and firm performance in Japanese manufacturing industries. Organization Studies, 31: 271-300.

Gerlach, M. L. 1992. Alliance capitalism: The social organization of Japanese business. Berkeley, CA: University of California Press.

Gillan, S. L. 2006. Recent developments in corporate governance: An overview. Journal of Corporate Finance, 12: 381-402.

Granovetter, M. 2005. Business groups and social organization. In N. J. Smelser \& R. Swedberg (Eds.). The handbook of economic sociology: (2nd ed.): 429-450. Princeton: Princeton University Press.

*Guan, Y.-D., Sheu, D.-F., \& Chu, Y.-C. 2007. Ownership structure, board of directors, and information disclosure: Empirical evidence from Taiwan IC design companies. Journal of American Academy of Business, 11: 182-190.

*Gul, F. A., \& Leung, S. 2004. Board leadership, outside directors' expertise and voluntary corporate disclosures. Journal of Accounting and Public Policy, 23: 351-379.

Hall, P. A., \& Soskice, D. 2001. Varieties of capitalism: The institutional foundations of comparative advantage. Oxford: Oxford University Press.

*Haniffa, R. M., \& Cooke, T. E. 2002. Culture, corporate governance and disclosure in Malaysian corporations. ABACUS, 38: 317-349.

*Haniffa, R., \& Hudaib, M. 2006. Corporate governance structure and performance of Malaysian listed companies. Journal of Business Finance \& Accounting, 33: 1034-1062.

*Hassan, H., \& Hoshino, Y. Stock option compensation in Japan: A test of alternative theories (working paper).

Hedges, L. V. 1982. Estimating effect size from a series of independent experiments. Psychological Bulletin, 92: 490-499.

Hedges, L. V., \& Olkin, I. 1985. Statistical methods for meta-analysis. Orlando, FL: Academic Press.

Heugens, P. P. M. A. R. 2007. Social institutions of capitalism. In G. Ritzer (Ed.). The encyclopedia of sociology: 395-398. Oxford: Blackwell.

Heugens, P. P. M. A. R., \& Otten, J. A. 2007. Beyond the dichotomous worlds hypothesis: Towards a plurality of corporate governance logics. Corporate Governance: An International Review, 15: 12881300 .

Heugens, P. P. M. A. R., van Oosterhout, J., and Vromen, J. J. (Eds.) 2003. The social institutions of capitalism: Evolution and redesign of social contracts. London: Edward Elgar. 
Holderness, C. 2003. A survey of blockholders and corporate control. Federal Reserve Bank of New York Economic Policy Review, 9: 51-64.

Hollingsworth, J. R., \& Boyer, R. 1997. Contemporary capitalism: The embeddedness of institutions. Cambridge: Cambridge University Press.

*Hovey, M. 2004. Corporate governance in China: An empirical study of listed firms (PhD Thesis).

*Hung, H., \& Mondejar, R. 2005. Corporate directors and entrepreneurial innovation: An empirical study. The Journal of Entrepreneurship, 14: 117-129.

*Hung, Y.-S., \& Wang, T. The determinants of the relationship between top executive stock-based compensation and performance measures: A study of Taiwan (working paper).

Hunter, J. E., \& Schmidt, F. L. 2004. Methods of meta-analysis: Correcting error and bias in research findings (2nd ed.). Thousand Oaks, CA: Sage.

Jensen, M. C., \& Meckling, W. 1976. Theory of the firm: Managerial behavior, agency costs, and ownership structure. Journal of Financial Economics, 3: 305-360.

Johnson, S., La Porta, R., López-de-Silanes, F., \& Shleifer, A. 2000. Tunneling. The American Economic Review, 90: 22-27.

Jung, K., \& Kwon, S. Y. 2002. Ownership structure and earnings informativeness: Evidence from Korea. International Journal of Accounting, 37: 301-325.

Kaufmann, D., Kraay, A., \& Mastruzzi, M. 2005. Governance matters III: Updated governance indicators for 1996-2004. Washington D.C., World Bank (working paper).

Khanna, T., \& Palepu, K. 1997. Why focused strategies may be wrong for emerging markets. Harvard Business Review, 75: 41-51.

Khanna, T., \& Palepu, K. 2000. Is group affiliation profitable in emerging markets? An analysis of diversified Indian business groups. Journal of Finance, 55: 867-891.

Khanna, T., \& Rivkin, J. 2001. Estimating the performance effects of business groups in emerging markets. Strategic Management Journal, 22: 45-74.

Kimura, F., \& Kiyota, K. 2007. Foreign-owned versus domestically-owned firms: Economic performance in Japan. Review of Development Economics, 11: 31-48.

Kisamore, J. L., \& Brannick, M. T. 2008. An illustration of the consequences of meta-analysis model choice. Organizational Research Methods, 11: 35-54.

La Porta, R., López-de-Silanes, F., \& Shleifer, A. 1999. Corporate ownership around the world. Journal of Finance, 65: 471-517.

La Porta, R., López-de-Silanes, F., Shleifer, A., \& Vishny, R. 1998. Law and finance. Journal of Political Economy, 106: 1113-1150.

La Porta, R., López-de-Silanes, F., Shleifer, A., \& Vishny, R. 2000a. Investor protection and corporate governance. Journal of Financial Economics, 58: 3-27.

La Porta, R., López-de-Silanes, F., Shleifer, A., \& Vishny, R. 2000b. Agency problems and dividend policies around the world. Journal of Finance, 55: 1-33.

Lai, A., \& Solomon, R. 2006. Ownership concentration and competition in banking markets (working paper).

*Lee, P. M., \& O’Neill, H. M. 2003. Ownership structures and R\&D investments of U.S. and Japanese firms: Agency and stewardship perspectives. Academy of Management Journal, 46: 212-225.

Li, P.-Y., \& Meyer, K. E. 2007. Contextualizing experience effects in international business: A study of ownership strategies (working paper).

*Lichtenberg, F. R., \& Pushner, G. M. 1994. Ownership structure and corporate performance in Japan. Japan and the World Economy, 6: 239-261.

*Limpaphayom, P., \& Polwitoon, S. 2004. Bank relationship and firm performance: Evidence from Thailand before the Asian financial crisis. Journal of Business Finance \& Accounting, 31: 15771600 .

*Lin, C. H., \& Shiu, C.-Y. 2003. Foreign ownership in the Taiwan stock market: An empirical analysis. Journal of Multinational Financial Management, 13: 19-41.

Lipsey, M. W., \& Wilson, D. B. 2001. Practical meta-analysis. Thousand Oaks, CA: Sage.

Loderer, C., \& Martin, K. 1997. Executive stock ownership and performance tracking faint traces. Journal of Financial Economics, 45: 223-255.

Maug, E. 1998. Large shareholders as monitors: Is there a trade-off between liquidity and control? Journal of Finance, 53(1): 65-98.

McConnell, J., \& Servaes, H. 1990. Additional evidence on equity ownership and corporate value. Journal of Financial Economics, 27: 595-612.

Miller, C. C., \& Cardinal, L. B. 1994. Strategic planning and firm performance: A synthesis of more than two decades of research. Academy of Management Journal, 37: 1649-1665. 
*Morck, R., Nakamura, M., \& Shivdasani, A. 2000. Banks, ownership structure, and firm value in Japan. Journal of Business, 73: 539-567.

Morck, R., Shleifer, A., \& Vishny, R. 1988. Management ownership and market valuation: An empirical analysis. Journal of Financial Economics, 20: 293-315.

North, D. C. 1990. Institutions, institutional change and economic performance. Cambridge: Cambridge University Press.

*Park, K. S., Lee, E., \& Jang, H. 2004. Why do managerial misconducts persist? The role of controlling shareholders in corporate governance (working paper).

*Peng, M. W. 2004. Outside directors and firm performance during institutional transitions. Strategic Management Journal, 25: 453-471.

*Peng, M. W., \& Jiang, Y. 2006. Family ownership and control in large firms: The good, the bad, the irrelevant - and why (working paper).

Pfeffer, J. 2007. A modest proposal: How we might change the process and product of managerial research. Academy of Management Journal, 50: 1334-1345.

*Pushner, G. M. 1995. Equity ownership structure, leverage, and productivity: Empirical evidence from Japan. Pacific-Basin Finance Journal, 3: 241-255.

* Ramaswamy, K. 2001. Organizational ownership, competitive intensity, and firm performance: An empirical study of the Indian manufacturing sector. Strategic Management Journal, 22: 989-998.

*Ramaswamy, K., Li, M., \& Pecherot Petitt, B. S. 2004. Who drives unrelated diversification? A study of Indian manufacturing firms. Asia Pacific Journal of Management, 21: 403-423.

*Ramaswamy, K., Li, M., \& Veliyath, R. 2002. Variations in ownership behavior and propensity to diversify: A study of the Indian corporate context. Strategic Management Journal, 23: 345-358.

Raudenbush, S. W., \& Bryk, A. S. 2002. Hierarchical linear models: Applications and data analysis methods (2nd ed.). Thousand Oaks, CA: Sage.

Roe, M. J. 1994. Strong managers, weak owners: The political roots of American corporate finance. Princeton, NJ: Princeton University Press.

Rosenthal, R. 1991. Meta-analytic procedures for social research (revised ed.). Newbury Park, CA: Sage.

Schulze, W. S., Lubatkin, M. H., Dino, R. N., \& Buchholtz, A. K. 2001. Agency relationships in family firms: Theory and evidence. Organization Science, 12: 99-116.

Selarka, E. 2005. Ownership concentration and firm value: A study from the Indian corporate sector. Emerging Markets Finance and Trade, 41: 83-108.

Shin, H.-H., \& Park, Y. S. 1999. Financing constraints and internal capital markets: Evidence from Korean 'chaebols.' Journal of Corporate Finance, 5: 169-191.

Shleifer, A., \& Vishny, R. W. 1986. Large shareholders and corporate control. Journal of Political Economy, 94: 461-488.

Shleifer, A., \& Vishny, R. W. 1997. A survey of corporate governance. Journal of Finance, 52: 737-783.

Stiglitz, J. 1994. Whither socialism? Cambridge, MA: MIT Press.

*Tam, O. K., \& Tan, M. G.-S. 2007. Ownership, governance and firm performance in Malaysia. Corporate Governance: An International Review, 15: 208-222.

*Tian, J. J., \& Lau, C.-M. 2001. Board composition, leadership structure and performance in Chinese shareholding companies. Asia Pacific Journal of Management, 18: 245-263.

Walsh, J. P., \& Seward, J. K. 1990. On the efficiency of internal and external corporate control mechanisms. Academy of Management Review, 15: 421-458.

Weidenbaum, M., \& Hughes, S. 1996. The bamboo network: How expatriate Chinese entrepreneurs are creating a new economic superpower in Asia. New York: Free Press.

White, H. D. 1994. Scientific communication and literature retrieval. In H. Cooper \& L. V. Hedges (Eds.). The handbook of research synthesis: 41-55. New York: Russell Sage Foundation.

*Yanadori, Y. 2004. Minimizing competition? Entry-level compensation in Japanese firms. Asia Pacific Journal of Management, 21: 445-467.

*Yeh, C.-C. 2005. The relationship between corporate governance and business reputation (working paper).

*Yoo, S. 2004. Do foreign investors enhance firm performance? Evidence from an emerging market (working paper).

*Yoshikawa, T. 2003. The impact of changes in ownership and control on performance of the Japanese corporation: Challenges to agency theory (working paper).

*Yoshikawa, T., \& Gedajlovic, E. 2002. The impact of global capital market exposure and stable ownership on investor relations practices and performance of Japanese firms. Asia Pacific Journal of Management, 19: 525-540.

*Yoshikawa, T., \& Phan, P. H. 2003. The performance implications of ownership driven governance reform. European Management Journal, 21: 698-706. 
*Yoshikawa, T., \& Phan, P. H. 2005. The effects of ownership and capital structure on board composition and strategic diversification in Japanese corporations. Corporate Governance: An International Review, 13: 303-312.

*Yoshikawa, T., Phan, P. H., \& David, P. 2005. The impact of ownership structure on wage intensity in Japanese corporations. Journal of Management, 31: 278-300.

*Yuan, J., \& Xiao, H. 2007. The joint effect of competition and managerial ownership on voluntary disclosure: The case of China. Journal of American Academy of Business, 11: 83-90.

Pursey P. M. A. R. Heugens ( $\mathrm{PhD}$, Erasumus University) is a professor of organization theory at the Rotterdam School of Management, Erasmus University. His research interests include bureaucracy and institutional theories of organization, comparative corporate governance, and business ethics.

Marc van Essen is a PhD student at the Rotterdam School of Management, Erasmus University. He holds an MSc degree in economics and law from Utrecht University. His research interests include shareholder activism, comparative corporate governance, and meta-analytic research methods.

J. (Hans) van Oosterhout ( $\mathrm{PhD}$, Erasumus University) is a professor of corporate governance and responsibility at the Rotterdam School of Management, Erasmus University. His research interests include the positive and normative theory of organizations and institutions, comparative corporate governance and management and governance of professional service firms. 